\title{
'Playing with space': a conceptual basis for investigating active sport tourism practices
}

Valérian Geffroy

University of Lausanne

Institut de Géographie et Durabilité

valerian.geffroy@unil.ch

$+41272057323$

This paper proposes a conceptual tool, the expression 'playing with space', for the analysis of active sport tourism as a meaningful social practice. The expression issues from practice theories and pragmatic understandings of space, which emphasize the processual and contextual dimensions of human action and seek to seize altogether the corporealities and shared conceptions that constitute action. On such views, sport tourists are considered as reflexive and embodied beings, enjoying sensations, mobilities and places, and constantly (re)making sense of their own practices. I argue that the notion of 'play' allows for a comprehensive understanding of the ways active sport tourists engage with space, where space is viewed as an object or material for this play. Three major dimensions of active sport tourism are then identified: a set of playful and game-like practices with global space resulting in shared imaginaries and large-scale mobilities; a kinaesthetic play, based on freedom and sensations and deeply engaged in the materiality of the places; and the omnipresent media practices that support the other dimensions of play while being fully integrated into the experience of sport tourism. This conceptual framework is a way to better understand the motives and practices of sport tourists; it is also a way to underline wider trends of contemporary leisure cultures: such cultures are increasingly integrated into the daily spheres of activity, increasingly playful and increasingly mediatized.

Keywords: play; space; practice; sport tourism; theory

\section{Introduction}

Figure 1. A rock climber's postcard picture of Kalymnos, Greece. (Reproduced by permission of J. Forster) 
This picture (Figure 1) is one of the most famous views, of one of the most famous places, for the rock climbing community: it has been shot from the back of the Grande Grotta, in the Greek island of Kalymnos. A climber is being lowered down from a route, seemingly overlooking the deep blue water of the Mediterranean Sea and the rugged island of Telendos. The landscape is spectacular, the climbing potential huge, the rock near-perfect and the atmosphere relaxed: everything is gathered to make of this place one of the world's major spots for climbing tourism. Such a picture, iconic of the practice of active sport tourism, is the result of many spatial actions and conceptions of space. The climber as well as the photographer have flown there from abroad, attracted by the reputation of the place and by the prospect of having a good time; the climber has ascended the route before dangling at the end of the rope, enjoying the said landscape and the satisfaction of having achieved a route perceived as beautiful. In many respects, it is a highly pleasurable experience of space.

By proposing to view active sport tourism as a playful practice of space, this article is an attempt to give one key, among others, to making sense of active sport tourism as a social practice. I will show how this perspective takes place in the present literature on sport, tourism and sport tourism; how this may apply to the several dimensions and several scales of those specific practices; and, in conclusion, how such a theoretical approach enriches our conception of sport tourism and places it in a wider social context. It comprises three main theoretical propositions: (1) it stresses the playful nature of active sport tourism, (2) it points to the centrality of the spatial dimension in this play, and (3) it puts forth the theoretical perspective of 'practice', which invites us to consider the corporeal actions as meaningful and conversely the understandings (or conceptions) as embodied, and shows how suitable it is to the analysis of active sport tourism.

The 'playing with space' perspective allows for a better understanding of the aspirations of participants, in part, because it considers them as playful beings rather than strictly rational consumers. 'Economical' approaches fail to seize the complex meanings attached to leisure practices, whereas the playful perspective promotes a more empathetic view of sport tourism, 
attentive to its pleasurable, aesthetic, gratuitous aspects, summed up in the enjoyment of space in its different dimensions. It emphasizes the open-endedness and the versatility of these leisure forms, which make them an actual practice rather than a pre-structured behaviour. This theoretical proposition, then, calls for deeper phenomenological understandings of active sport tourism (following for instance Shipway \& Stevenson, 2012); while still acknowledging the power of the different 'frameworks' (social, economic, spatial...) of the action and the experience. Such a synthesis is allowed by the 'practice theory' (Schatzki, Knorr-Cetina \& Von Savigny, 2001); one of its purposes is indeed to overcome the dichotomy of subjectivism against objectivism (Bourdieu, 1972).

\section{I- Sport tourism defined and theorized}

\section{A relevant field of practices}

The efforts for defining the field and the concept of 'sport tourism' have been numerous in the last few decades. They stem from various perspectives and goals but amount to a collective attempt to conceptually delineate the group of phenomena that is intuitively and empirically described as 'sport tourism'. In order to draw 'operational' frameworks, several authors have proposed classificatory perspectives of such phenomena, claiming to ground them in empirical observations rather than theoretical definitions (Bouchet \& Bouhaouala, 2009; Kurtzman \& Zauhar, 2003). In doing so, they intend to encompass all significant sets of practices where sport is associated with a tourism experience; but they do not satisfactorily address the specific phenomenon that results from the blending of the two domains (Gammon, 2015). These works have been helpful especially in the identification of an economic sector and the offers, markets and consumer profiles within it. But such classificatory definitions have been brought a little further, notably by Gibson (1998b), who defines sport tourism as:

leisure-based travel that takes individuals temporarily outside of their home communities to participate in physical activities, to watch physical activities, or to venerate attractions associated with physical activities. (Gibson, 1998b, p. 49) 
The Version of Record of this manuscript has been published and is available in Journal of Sport \& Tourism, 29 Dec 2016 , https://www.tandfonline.com/doi/full/10.1080/14775085.2016.1271349

Indeed, this definition appears to cover the whole spectrum of activities that the different authors label as 'sport tourism', and provides a categorization that clearly distinguishes different domains: event sport tourism ('to watch'), nostalgia sport tourism ('to venerate attractions') and active sport tourism ('to participate'). Moreover, it includes a definition of the 'tourism' concept itself, which provides a basis for questioning the individual meaning of sport tourism. That is to say for asking, as Gibson (2006) puts it, 'Why do sport tourists do what they do?'; or more precisely, 'Why do they go away to participate in or watch sport?'. The purpose, then, is not only to describe such behaviours, but also to analyse and explain them (Weed, 2006); to consider them as socio-cultural practices rather than mere consumption patterns. This approach is illustrated, for instance, by Standeven and De Knop's (1998, p. 58) characterization of sport tourism as a '[cultural] experience of physical activity tied to a [cultural] experience of place'. It is also the ground of one of the most comprehensive definitions of sport tourism, proposed by Pigeassou (2004), that I will here accept:

a travel, creating a touristic time-space, initiated by a place (viewed as a destination) and by the participation in a sport culture under the form of a physical activity or a cultural manifestation. ${ }^{1}$ (Pigeassou, 2004, p. 45)

Two main bodies of literature may then be identified. The first body consists mainly in applied research aimed at addressing the stakes and issues of the industry of sport tourism (Glyptis \& Jackson, 1993, quoted in Gibson, 1998b). It has extensively demonstrated the relevance of sport tourism as an economic sector. But it has also led to underestimation of some of its significant practices. For instance, active sport tourism, as Gibson (1998b) points it out, is neglected by tourism professionals, who are often focused on the hosting of large sporting events. Thus, probably because it is more difficult to evaluate the expenses related to active sport tourism than those related to feebased sporting events, its economic importance is underestimated. The second perspective would consist in efforts to show that sport tourism is also a meaningful social and cultural practice. The two perspectives are frequently intertwined; but they broadly correspond to different disciplinary positions. Among the social sciences, three disciplines at least have fruitfully analysed sport 
tourism: sociology, anthropology and geography. Research has been conducted through sociological frameworks in order to analyse the communities and subcultures built around particular sports, travel being a way of creating shared references and of acquiring a symbolic capital (Kane \& Zink, 2004; Lamont, 2014; Pociello, 1999). Anthropological studies have insisted on the meanings attached to the experiences, for personal identities and within the communities (Rickly-Boyd, 2012; Varley, 2006). And, lastly, the geographical perspective has provided opportunities to investigate the sense of place grounded in sport tourism experiences (Kulczycki, 2014), or even more frequently the territorial effects of such activities (Bourdeau, Corneloup, Mao, \& Boutroy, 2004; Higham \& Hinch, 2006).

It is this effort, concomitant with the second perspective, to grasp sport tourism as a meaningful social practice that the present article aims to contribute to. However, the conceptual proposition of 'playing with space' is unequally relevant to the earlier-mentioned categories of sport tourism practices. It aims primarily at the category of practices that Gibson (1998b) has named 'active sport tourism' (i.e., travelling to participate in a sport activity). Indeed, as will be developed in the next section, the proposition here acknowledges active sport tourism as a bundle of multiple engagements with space, and characterizes these engagements as fundamentally playful. The nonparticipative forms of sport tourism (event and nostalgia sport tourism, in Gibson's classification), of course, engage with space, but in different, more distant ways. The kinaesthetic practice of space through the sport activity in particular, which engages the body in the very material environment, is absent or merely incidental in non-participative sport tourism, whereas for active sport tourists it is, I argue, a crucial source of enjoyment. Hence, the scope of this paper will be restricted to active sport tourism. Active sport tourism practices are diverse; they take place in many different environments, areas, spots. But whether it be in the 'wilderness' or in urban surroundings, the motivation to travel to these spaces of practice is expressed, as I will argue, in terms of beauty, of uniqueness, of atmosphere, of myths, and so on. In relation to these criteria and under the influence of the sport activity, places are coded, interpreted as enjoyable. Thus, active sport tourism is 
essentially the desire to practice an enjoyed sport in such enjoyable places - except in a few cases where the main or sole interest for travelling is to participate in an event and to experience a subculture (Green \& Chalip, 1998). The perspective developed here encompasses, then, a wide range of sports, from those labelled as 'outdoor' or 'adventure' - kayaking, trail running, rock climbing - to urban running, golf and cycling.

\section{A theoretical proposition}

The present contribution is intended to be a theoretical proposition, for it develops a useful way of viewing active sport tourism - using the notion of playing with space as a frame for analysis. The choice of such an explanatory perspective inevitably sets aside some other key components of the tourism phenomenon; hence, it is by no means a comprehensive conceptual framework - nor is it a definition of active sport tourism. It is a situated approach. In the present section, I detail its theoretical grounds.

This approach is, first of all, focused on the spatial dimension of practice - or spatiality. It is, undoubtedly, the geographer's point of view that space is central to tourism; but many other theorists have acknowledged this as well, by making place a key concept in their study of tourism (Baerenholdt, Haldrup, Larsen, \& Urry, 2004; Sheller \& Urry, 2004). The notion of place, however, is only one of the categories of the concept of space, as in the influential definitions of Tuan (1977) - place is 'space infused with human meaning' - or Massey (2005) - place is a selected part, a 'collection' of the 'simultaneous stories' that constitute space. A much wider concept, space is 'one of the dimensions of society, constituted by the set of relations that distance establishes between realities' (Lévy \& Lussault, 2013, personal translation). Thus, understandings of 'space' range from the abstract and geometrical one, to the lived intimacy of the immediate surroundings of the body; and the notion of space encompasses those of distance, topology, arrangement, territory ... and place. There has been a shift in social theory from notions of space as objectual and fixed to the acknowledgment that space is, as Massey (2005) states it, relational, made of heterogeneity, and always under construction. The concept of 'spatiality' - 'the modes in which space is implicated in 
the constitution and conduct of life on Earth' (Gregory, 2009) - has thus been increasingly used. These renewed conceptions have led geographers (among others) to free tourism analysis from narrow conceptions of space and place and, for instance, from the traditional idea of clearly demarcated and fixed 'destinations'. Many of them now prefer to view tourism as one form of mobility amongst others (Hall, 2005), putting the emphasis on the movement rather than on the stay, or even as a new - fundamentally mobile - form of 'dwelling'2 (Stock, 2006). Tourist places are increasingly understood as constructed, activated, used, worked and reworked: in a word, they are performed (Baerenholdt et al., 2004), and in a particularly rich way compared to daily places, as well as in a consistently embodied way (Crouch, 2000). Such analyses of course apply to sport tourism in a general sense. But in addition, sport tourism bears specific relations to places and the environment. As Higham \& Hinch (2006, p. 32) put it, if place is 'space that is infused with meaning', then for our case it is sport that 'infuses tourism destinations'. Sport tourism activities offer a particularly strong place experience through bodily commitment (Crang, 2004, quoted in Higham \& Hinch, 2006), and often through an aesthetical appreciation of the physical environment. For these reasons, sport tourism practices elaborate places in their own way, and their analysis should acknowledge the uniqueness of these elaborations (Gammon, 2015; Weed \& Bull, 2009). Here, the meaning and the making of places will be addressed as one of the spatialities, among others, of active sport tourism. The concept of space is indeed used in its multiple dimensions, with the multiple meanings it may have for sport tourism practices: a network of significant places; $a$ space in the sense of a bounded portion of territory; a set of resources, obstacles, materials that allow and/or constrain action; and so on.

These now widely accepted interactionist and constructivist postulates also constitute the ground for our second theoretical mooring, the practice theory - or rather the practice 'perspective', since it is less a coherent theory than a wide set of converging propositions. It is indeed, as Schatzki (2001) synthesized it, a label for the range of efforts to overcome problematic dichotomies of the social sciences such as action/structure or objective/subjective. Although it is not unified, 
a central core $[\ldots]$ of practice theorists conceives of practices as embodied, materially mediated arrays of human activity centrally organized around shared practical understanding. (Schatzki, 2001, p. 11)

Analysing social phenomena through the notion of practice is a way of avoiding a separation between actions and conceptions; to consider that meaning is constructed in-the-doing, involves the body and the materiality, and emerges through a certain regularity of actions. And space is essential to the analysis of human practices, since it is one of their dimensions (Schatzki, 1991): social practices do not 'take place' in externally defined spaces, they 'make and have spaces' (Schatzki, 2015). In a similar but reversed perspective, some authors have proposed pragmatic understandings of space and spatiality. Lussault \& Stock (2010), for instance, propose an expression, 'doing with space', that allows (1) stressing the processual dimension of relations with space, (2) taking into account the materialities they involve, (3) viewing space as a set of primary resources - and obstacles - for, rather than as a container of, actions. Such a perspective allows us to address the multifarious engagements of humans with space, not as something we 'are in', but as something we 'do with'. This perspective directly inspired the present contribution, which specifies it in 'playing with space, ${ }^{3}$ on the postulate that sport tourism is fundamentally a playful practice of space.

Johan Huizinga has been one of the first thinkers to theorize the playful dimensions of human activity and society (Huizinga, 1938). He defines play as (1) freely initiated, (2) pleasurable, (3) temporary and distinct from ordinary life, (4) restricted by rules and creating an order, and (5) implying a certain degree of tension and uncertainty. His definition, however, does not entirely cover the field of the playing activities, for two reasons: he only considers, as he puts it, 'the play of a social type'; and the notion he writes about, which can be translated into 'jeu' in French, or 'Spiel' in German, for example, corresponds to two distinct English terms, 'game' and 'play'. The latter is a more general concept than the former: it includes not only the interactions structured by precise rules that we call 'games', which approximately match this 'play of a social type', but also unconstrained actions - or even movements - associated with pleasure. Roger Caillois (1958), trying to further Huizinga's theories, has proposed a classification of games and playing, in four 
distinct types which can also meet in a given instance: agôn, or the competition; alea, or chance; mimicry, or acting, dressing, simulating; and ilinx, or sensations issuing from speed and vertigo. He has also proposed to place the different types of play along a continuum from ludus, the most structured forms of play, to paidia, for playfulness, the more spontaneous and unconstrained forms. Since the proposition here developed views, in particular, the kinaesthetic dimension as of great importance, I intend to address the entire continuum of play, the whole spectrum of playful activities, the ruled and orderly ones being only part. Active sport tourism, as I will try to show, encompasses this whole spectrum, from the very material and physiological plays of the body to the more abstract types of play, and even some kinds of games. Stressing the playful dimension of active sport tourism is also a way of situating it in the theory of leisure, which is of growing importance in social theory. Dumazedier (1962) has coined the expression 'leisure civilisation' to express the rise of leisure as a central theme for society. Elias and Dunning (1986) have proposed to conceive sport as a key element of the 'civilising process', for it provides an arena of 'pleasurable' and 'controlled excitement' and helps maintain a peaceful society through a measured unleashing of emotions and tensions. Recent research in tourism (Équipe MIT, 2002) suggested that play is one of the core elements of 'recreation' - understood as a quasi-synonym for 'leisure' as well as, etymologically, as a renewed creation of the self through the rupture with daily routines and constraints. But this search for rupture may be less obvious than it once was: tourism research indeed observes a trend of 'de-differentiation of everyday life and touristic experiences' (Uriely, 2005). At least in (rich) societies where they have become commonplace, tourism practices are more and more integrated to the other spheres of activity and to the daily time-spaces. A practice of multiple temporalities and multiple scales, a practice of individuals committed to their sport on a regular basis, active sport tourism is, I will argue, at the edge of these contemporary evolutions of leisure. 


\section{II- Playing in multiple ways, at multiple scales}

Active sport tourism encompasses various time-spaces, various affects, various projects and actions. In this section, I illustrate the variations of this play with space that constitute active sport tourism while also acknowledging the continuum linking them. I detail how the expression 'playing with space' may be applied at different scales, at the different dimensions and subsets of practices of active sport tourism - first, at a global level, with conceptions, imaginaries and mobilities; second, at a local and micro-local level, in kinaesthetic enjoyment of the physical environment and aesthetic appreciation of the settings; and third, on a discursive level, with images and information shaping the practice and taking part in it.

\section{'Toying with the idea' of going away}

Tourism begins at home. It is in the time-spaces of our daily lives that we dream of travelling (or fear it), that we acquire knowledge - even scarce - of foreign and exotic lands, and that we prepare for our next trip or remember our last one. It is a play of the mind, but not solely; tourism also involves a wide array of social relations, media productions, and cultural models; it involves everything that contributes to our building conceptions (Schatzki's (2015) 'sayings' as distinct from 'doings') of tourism places and experiences. It is a play made of worldwide imaginaries, a play that may result in long-distance mobilities.

Above, it was said that active sport tourism is travelling for the practice of sport. This constitutive relation has been further characterized by Pigeassou, Bui-Xan \& Gleyse (2003, p. 30) who suggest a 'link of subordination' of the travel to the sport 'medium', as well as Gammon \& Robinson (1997) who attempt to distinguish different types of sport tourism based on the 'primary motivation' of the tourists. Hard as it may be to sort out the multiple motivations underlying a trip, there are several examples of practices where sport and tourism actually are consubstantial. The specialized media are filled with accounts, stories and expressions that explicitly associate the travel or trip with the sport: 'surf trips'4, 'climbing trips ${ }^{5}$, 'kayaking tours' (Kane \& Zink, 2004) and so on. An increasing panel of tour operators and professional guides offer such travel experiences; and 
while the practice of and market for these kinds of sport tourism are developing today for a variety of sports, surf tourism in particular already has a long history. It is now an 'industry' of hundreds of thousands of tourists a year, with hundreds of dedicated companies offering 'surf camps' or 'liveaboard surf charters' (Thorpe, 2014, p. 116). In these cases, the sport is decisive in the choice of the destination; it frames the daydreaming and the anticipated enjoyment of the places to go.

Space, at this global and conceptual level, is mobilized in these practices as a raw material of freedom. Sport tourists, especially if affluent or committed enough to travel the entire world, may develop abilities for mobility, such that the world becomes a vast 'playground'. By pursuing their sport around the globe, they - each at their own level - epitomize ideals of hypermobility that pervade society in general, but that are even more prominent in certain alternative subcultures. Praising the freedom attached to mobility and movement takes an important part in this 'alternative' identity (Thorpe \& Rinehart, 2010) that many sport communities profess, often to the point of granting a heroic status to those who give up the comfort of permanent residence and employment to 'pursue their dream': the 'van dwellers', the 'ski bums' (Thorpe, 2014), the 'dirtbags' (RicklyBoyd, 2012). But even for those whose travel practices are more occasional—viz., actual sport tourists - going away allows to transfer the daily or regular activity to exceptional and out-of-theordinary places and moments. Frequently, the most committed of them profess that their sport is more of a 'lifestyle' (Rickly-Boyd, 2012; Wheaton, 2004); and their trips take place in the most valuable and desirable moments of this life. Hence, among the most frequent themes emerging from the narratives of surf tourists, when asked to remember their surfing trips, are 'living surfing' and having ‘indelible experiences’ (Barbieri, Henderson, \& Santos, 2014).

Instrumental in this global play with space are the world maps, provided by various sources, that mark the 'world's best spots' and/or exhaustively list the known locations for the practice of the sport. Such maps are frequent in magazines as well as on websites (either commercial or community-based $)^{6}$. They are instrumental in the formation of 'geographical imaginaries' (Debarbieux, 2003; Gregory, 1994) of the world as a playground for sport enthusiasts. Hence, they 
are one of the most obvious signs of the constitution of a globalised touristic space of sport activities. Moreover, when such maps are digital and 'browse-able', they are one of the tools that allow us most literally to play with space; one can indeed roam with unequalled freedom and easiness through topographical representations of the world. The virtual globes and the 'googlian zoom $^{7}$ (Lussault, 2007) are a decisive innovation in this regard: indeed, being able to shift instantaneously from one scale to another is a 'skill' that no previous technique could offer. It contributes to rendering the local scale more directly available for the mind to grasp; it allows us to mentally link the place to a global perspective. It is of an undeniable importance for tourism and travel practices: browsing effortlessly through virtual globes and 'visiting' iconic places in this manner is most certainly today a powerful tool for daydreaming.

Such maps, then, strongly contribute to the creation of common conceptions of the world within sport subcultures. As an illustration, the Austrian climbing and outdoor clothing firm Chillaz manufactured a T-shirt bearing a 'climbing map' representing the 'destinations where you should have been ${ }^{8}$. It takes the shape of a subway plan, each station being a famous rock climbing area. This playful analogy with urban space and networks shows how a global touristic imaginary can condense sport sites into connected and accessible places. But like every other sport-specific piece of clothing, and especially those that display referential messages or images, it is also a way to claim one's membership of a subcultural community. It is indicative of the significance of travel for positioning oneself in such communities. Processes of symbolic capital accumulation (Bourdieu, 1972) have been extensively investigated within sport cultures (Pociello, 1999) as well as within travel practices: these processes have been described as a 'career' (Pearce \& Caltabiano, 1983; Pearce \& Moscardo, 1985), where individuals get rewards and prestige for travelling. Selffulfilment is one aspect, but it is also strongly tied to the social recognition it brings; thus, such a perspective is particularly relevant for communities of committed people with shared references, such as sport subcultures. 
Leisure activities in which people commit deeply have been investigated and labelled 'serious leisure' by R. Stebbins (1992), who also uses the notion of 'career'. It appears to be a remarkably useful framework for sport tourism practices (Jones \& Green, 2006). The 'playing with space' approach is in no way opposed to that of serious leisure, and playfulness is not antagonistic with seriousness. Indeed, if sport tourism is essentially a playful and pleasurable activity, it is also highly socially and symbolically rewarding, and thus frequently taken seriously. Kane \& Zink's study (2004) for example highlights the prestige associated, within the kayaking community, with practices and places viewed as adventurous, remote and physically and technically demanding. Lamont (2014), analysing cycling tours in the French Alps, shows how 'doing' (p.13) mythical passes provide the tourists with feelings of achievement, and how sharing their performances is part of the pleasure. Thus, active sport tourism practices may partly rely on games. They feature many aspects of competitive play, and thus may belong to Caillois' category of agôn. They take place in hierarchical and partly enclosed universes; they allow progression through the acquisition of skills and the accumulation of experience; they may bring symbolic rewards; and in this game, space is a central stake. It is indeed places that are collected (Kulczycki, 2014), because of the specific values attached to them.

The worldwide imaginaries of active sport tourism, as well as the motivations inherent to the sport communities, fuel large-scale mobilities. Active sport tourists are indeed highly mobile individuals (Thorpe, 2014), with enough economic and cultural capital (Gibson, 1998a) to travel the world. Thus, for them, global space is a 'material' they easily play with - space in this sense is more a set of resources for fun, leisure and freedom, than a set of barriers and obstacles, as is often the case for individuals who hold less or no capital. Hence, playing with space, for active sport tourists, begins with travelling the world, both physically and imaginarily.

\section{Bodies, space and matter: a kinaesthetic and aesthetic play}

It is also at the bodily level that active sport tourism is, most literally, a play with space. This is of course true for sport considered alone; but the specific relationship to place and space 
brought by the tourism project transforms even the bodily dimension of the sport practice. In particular, it ties closely the micro-local physical experience of space to the appreciation of the perceived environment - as a landscape, as a site, a 'spot', etc. In this section, then, I will discuss active sport tourists' playful engagements with space at the micro-local and local scales.

Different sports have different ways of playing with matter and space. They vary in particular in their degree of 'freedom': while some sports rely on the simple pleasure of free movement in a simple environment (running or swimming, for instance), some others imply technical devices, sophisticated rules or infrastructures which frame the actions performed in and with space. Enjoyment and thrill may be found in all of these practices, especially when accompanied by a feeling of mastery. But tourism projects and practices are supported in particular by the sports which take place in less standardized environments; especially important in this perspective, and in the field of active sport tourism in general, are the 'outdoor sports'. The denomination is more of a common term than a precise concept; here 'outdoor sports' are understood as sports which deal with non-standardised and/or changing environments, be they 'natural' or urban (in the cases of urban marathon or 'street sports' for instance). These sports essentially proceed by adaptation to and immersion in space and matter, by dealing with irregularities of the terrain, urban landscape or moving elements. Such sports develop a play restricted only by physical features of the environment and flexible conventions, which are mainly related to ethics or style but do not strictly define the sport. This freedom is one of the core values of the 'cultural revolution' (Loret, 1995) of the sport universe that took place in the last quarter of the $20^{\text {th }}$ century and resulted in the creation of a myriad of - mainly outdoor - new sports, but also in significant changes or innovations in the more traditional ones. This transition put a strong emphasis on fun, sensations, nature, style; it was particularly embodied in sports based on the act of gliding through or riding a natural element - mainly water, air or snow - or an artificial surface. They were grouped under the expression (coined by Bessas, 1982) 'sports de glisse' in French. The term refers to a way of moving by sliding or gliding (with or without a board), but it also expresses 
the sensation inherent to this movement. It is a very strong feeling, best defined poetically or metaphysically, as Loret (1995, p.131) states, quoting Bessas' words 'trance', 'energy' and 'communion'. Loret goes as far as extending the label 'sports de glisse' to activities such as climbing or running, which do not involve any sliding or gliding, but may bring intense feelings of freedom and harmony: for instance, 'aerobatic pilots [speak] of the pleasure and beauty of controlled movement in space' (Slanger \& Rudestam, 1997, quoted in Brymer \& Gray, 2009, p.142). In that perspective, the notion is quite close to Csikszentmihalyi's 'flow' (1991), which, being a state of 'intense focus and psychological energy' (Rickly-Boyd, 2012, p. 86), has proven particularly useful to analyse the psychological effects of such sports. Interviewed rock climbers, for example, have extensively described their impressions of 'timelessness', 'one-pointedness' and 'integration of mind and body’ (Csikszentmihalyi, 1975; quoted in Rossiter, 2007, p. 294). Thus, the play characterizing these sports is to a large extent of Caillois' ilinx — that is to say the pleasurable blurring of perception and heightening of sensations. Sports have increasingly searched for freedom of movement, and the tendency to multiply jumps and flights and to emphasize verticality (Loret, 1995) may even be seen as an attempt to free the body from its two-dimensional movement pattern, to actually allow one to playfully move through space.

But sport is also always moving - and playing - with space and matter. Thus, active sport tourism is also the search for an intense and pleasurable contact with elements. Frequent are the descriptions referring to the haptic sense and to a relation of harmony and with the elements, their movements or textures:

I feel the water rushing past my feet and legs. [...] The delight and sensation when surfing down a small wave with the sail beautifully balanced by the wind. (Humberstone, 2011, p. 502)

I feel that I'm going with the flow of the waterfall and it's letting me out at the bottom and I'm still in the hands of the waterfall, it's going along with me. (Brymer \& Gray, 2009, p. 143)

The latter words are of a kayaker the authors interviewed while conducting an ethnographic study with so-called 'extreme' sports participants, who astutely express the blend of bodily sense of 
harmony and ecosystemic consciousness that makes them deeply enjoy their sport practices.

Outdoor activities are indeed widely considered among the participants as a privileged way to connect with 'nature'. Such conceptions are often supported by a strong ecological awareness (Brymer \& Gray, 2009). Hence, this intense corporeal relationship is particularly often drawn with reference to nature, although it may as well build on the urban environment, or on a bike and a road (Spinney, 2006). This bodily relationship with matter is a source for a variety of sensual pleasures, and sexual depictions of those are not rare:

with the sports de glisse, you have to learn not to fight, but rather to make love to nature, that's to say to discover it, to love it, and finally to play with it. ${ }^{9}$ (Yves Bessas in Victor, 1981)

In such relationships, the body is understood as merging with the environment, and thus not left intact. Rossiter (2007) analyses the practice of climbing as 'intercorporeal', a 'mutual defacement' where the climber marks the rock (with chalk and gear) and the rock marks his/her body in return. It is through this intimate relationship that the climb is elaborated and that climbers experience 'energy flows'. Lewis (2000) details how the 'climbing body' becomes dedicated to immersion in the cliff and in the wider environment, in a kinaesthetic manner; how it is inscribed with meanings shaped by this physical environment. The climber's hands in particular, hardened and strengthened, regularly scratched or wounded by the contact of the rock, become the 'talismanic part of the body' (Lewis, 2000, p. 72). Thus, the body is instrumental in the way active sport tourists perform places. The enjoyment of place is grounded in the partly free and partly unconscious play of the body (Thorpe \& Rinehart, 2010).

But the in situ play with space deployed in active sport tourism is also drawn on a slightly larger picture: that of the aesthetic enjoyment of the environment at a local scale, in particular as a landscape. Again, though the 'natural' environment is a central object of awe, urban atmospheres are enjoyed as well: 
Kayakers expressed their appreciation for the beauty of the natural environment in which their activity took place and the pleasure of intimacy with the rivers, getting to know their various characteristics and idiosyncrasies. (Slanger \& Rudestam, 1997, pp. 370-371)

[In Adelaide t]here are some beautiful rides and some nice little quiet roads through the trees, and it's just beautiful for riding. (Shipway, King, Lee, \& Brown, 2016, p. 28)

Similarly, the tone of narratives found in the specialized media is often poetical or lyrical. The shared conceptions of the practices and their places are widely aestheticized; the landscape's beauty and pleasures are extensively praised, as for instance those of the Calanques cliffs in Marseille:

a place where we climb for ourselves, to enjoy the essence of the place, the sublime surroundings, the atmosphere and the salty air. ${ }^{10}$ (Dechamboux, 2015, p. 108)

However influential, the professional media are only one source among others for the creation and perpetuation of shared understandings of space; meaning is permanently (re)produced in the time-spaces of active sport tourism, 'in-the-making' of the sport activity, even on an unconscious level (Ness, 2011). Every sport activity has its own way of playing with the physical environment's textures, features and properties; thus, for every sport exists a specific poetics of space. Paragliders search for warm air columns and spectacular mountains to fly over, surfers search for warm clear waters and perfectly shaped waves, rock climbers search for smooth or gritty rock and bright-coloured cliffs, and so on. And this, in large part, is what fuels sport tourism imaginaries and trips.

\section{Media practices: an integral part of the play}

The 'playing with space' approach allows us to theorize the global conceptions of sport tourism as well as its corporealities; and recognizing the insights of theories of practice, I have endeavoured in the above to highlight the consistent relation between conceptions and actions. This constitutive link is fully understood only when examining the processes of creation and actualization of understandings through action. Instead of conceiving of sport tourists as merely following pre-defined understandings of places, travel and sport, we have to describe the 
mechanisms of creation of meaning. And active sport tourism practices are particularly illustrative in this perspective; as for tourism practices in general, they indeed extensively display, through abundant imagery and discourses, the ways in which understandings are negotiated.

In this play of picturing places, of longing for powerful experiences and remembering them with delight and emotion, the professional media hold a central position. The specialized magazines belong to the most influent of the media producers, even if, as we will see below, they no longer hold the monopoly of the media contents. The magazines often contribute to the creation of sport tourism sites by reporting their discovery and early frequentation - usually by the sport's elite; they publish travel accounts and stories, often accompanied by practical guides, thus building the reputation - sometimes the myth - of the best places to travel to, or the most beautiful, or the most exotic; they nurture shared conceptions and representations of these places, usually supported by numerous pictures of their landscapes and of the physical performances that take place in them. The surf media imagery, for instance, appears to be decisive for the choice of undertaking a trip, as surf tourists themselves state in Ponting \& MacDonald's (2013) study. There might be specific features exerting a particularly strong attraction to the place — a unique element in the physical environment, or the historical or mythological status of the site for the subculture, or even non-sport-related aspects, like the local food or the hospitality of local people. But there are also key elements that, for each sport, compose a shared conception of the ideal site, of the perfect place. For the surfing culture, Ponting (2008) found that the 'Nirvana' myth relies on four pillars: perfect waves, uncrowded conditions, cushioned adventure and a pristine tropical environment. The professional media hold a decisive role in the determination of these conceptions (idem, pp. 50-57). The media imagery and discourses are co-constructed by the tourists themselves; nevertheless, especially in the pre-trip phase, where the play with the global networked space is mainly performed through the mind and the eyes, the specialized media are both a popular material and a leading force.

Instrumental to the global 'mind-wandering' of active sport tourism, media imagery is also instrumental to the micro-local bodily play, and increasingly so, due to technological innovations 
and related cultural evolutions. I argue here that media practices - understood as 'the open set of practices relating to, or oriented around media' (Couldry, 2010, p. 36), and thus covering the consumption as well as the production and sharing of images and discourses - bridge the different types and scales of play studied in the previous sections into a continuum, and contribute to merge them into a homogeneous set of practices. Indeed, whereas a few years ago the media production was almost monopolized by professionals, it is today widely accessible, and individuals are all the more active in the creation and actualization of social and cultural shared understandings. The key factors of this evolution are the digitalization of information and the generalization of access to the Internet. For active sport tourism specifically, it translated into significant changes in the way practices are pictured and performed; and media practices have become an essential dimension of sport tourism as a whole.

Firstly, the manipulation and circulation of images and discourses has been considerably facilitated. The relations of individuals to media and audiovisual material in particular have become more active and more playful (Ardèvol, Roig, San Cornelio, Pagès, \& Alsina, 2010). The quantity of material produced by and accessible to individuals has increased considerably. It is now widely used as a constitutive element of the 'social play', mainly through digital networks. For action sport participants in particular, who are avid producers and consumers of specialized media (Thorpe, 2014), there exist dedicated community 'spaces' on the internet where images and narrations can be shared by anyone ${ }^{11}$. They are used both as information sources and socialization spaces: they aid in the sharing of experiences and practical information on places, the preparation for and reporting on trips and outings, and even the simple contemplation and picturing of potential ones. The generalist online social networks, however, may play the most important role. Indeed, today, they work as the main 'stage' of 'self-presentation' (Goffman, 1973). Sharing images of oneself in action could be seen as the final step of 'performing' sport, tourism or sport tourism; complex meanings are created in tourism situations through the action taking place in specific settings, in specific ways (Edensor, 2000). For instance, Lamont (2014, p. 10) has found that 'almost all [the cycling tourists] 
interviewed spoke of strategies for digitally immortalizing their experiences', and through that 'facilitated dissemination and perpetuation of the authentic status of [the Tour de France] sites'. So tourists do not just take for granted pre-defined understandings of space, they create their own; and often the self is extensively displayed in their media production. Sport or 'adventure' tourism practices are notably present in this self-presentation imagery, for they display strongly positive values of activeness, healthiness, open-mindedness and proximity with nature. By presenting themselves in such a light, active sport tourists are performing a play of a theatrical type, a sort of acting, as it has been widely theorized in tourism studies (Edensor, 2000). Thus, the consumption and production of images and discourses by active sport tourists is inherently playful. This statement encompasses at least two functions of the media practices, as Woermann (2012) argues: the pleasure that they provide ('hedonic practices') and the negotiation of conceptions and understandings (both of self and of common practices) that they allow.

Secondly, media production and consumption have been directly integrated into the timespaces of the physical activity: they are part of the play even as an embodied practice. Woermann (2012) analyses freeskiing practices and underlines the amount of time and energy spent to produce videos of a few seconds:

[For] no more than 120 to $180 \mathrm{~s}$ of 'pure action' a day, when the skiers are actually in the air and performing a trick, hours and hours of leisure time are dedicated to seeing others (both offand online) and to producing the visual media to be seen. (Woermann, 2012, p. 621)

Woermann claims that mediatisation should thus be comprehensively viewed as a set of societal and cultural practices, and not reduced to the final contents. For our case, they can be considered as an integral part of the active sport tourism practice. Recent technological innovations have contributed greatly to the integration of media practices into the action, even shifting them to a more directly embodied style as with action cameras. Small, light and protected (from water, from shocks, etc.), these devices are designed to be carried easily or fixed onto various pieces of gear (helmets, boards, etc.). They allow the capturing of images from an individual point of view, and in action. The result 
is a seemingly instantaneous and almost 'unmediated' mediatisation of bodily practices, which is perceived as a 'true' and spectacular representation of the kinaesthetic experience. But interestingly, action cameras are increasingly used for non-sport practices, notably in tourism or leisure practices in general ${ }^{12}$. This suggests the generalization of a new style of media practices, which borrows from the 'tourist gaze' (Urry \& Larsen, 2011) an emphasized enjoyment of place, and from the sport media the focus on the sensuous body. Such innovations, along with cultural changes, have made media practices easier and more directly enjoyable; more accessible, and thus more playful.

In fact, active sport tourism practices are in this regard representative of wider evolutions of the contemporary leisure cultures.

\section{III- Conclusion}

What does active sport tourism tell us about leisure in contemporary societies? The conceptual perspective of 'playing with space', I argue, is particularly effective to answer this question: it addresses some of the core issues of leisure and tourism.

It is indeed a way of putting forth kinaesthesia, embodiment, and the lived experience as primary aspects of active sport tourism, while still acknowledging the power of conceptions and imaginaries. The notion of play is in this regard particularly useful, for it encompasses all of these dimensions: there are plays of the mind as well as plays of the body, and many involve both. Thus, I argue, 'play' could be further developed within the theories of practice, as a central concept.

It is also a way of acknowledging the more-than-ever central role of 'mediatisation' of the practice. Actions, movements, mobilities, environments, places: all of them are put into discourses and images, carry meaning and build shared conceptions. Media practices should not, then, be viewed as secondary, substitutive ways of experiencing the world; but as expressions and vehicles of this meaning-making. In turn, research should give more importance to these practices, especially by exploring the continuum between home and away, production and consumption.

The conception of space embedded in the expression, as mobilised in multiple ways, through actions and conceptions, is a way to move away from the view of fixed and bounded 
'destinations', towards more multidimensional understandings of space, acknowledging the worldwide mobility imaginaries as well as the importance of the micro-local scale of the body. It is a way of calling for pragmatic and relational approaches of space in empirical research: active sport tourists should be asked about how they negotiate and 'produce' places and space, with attention to the ways they enjoy them, rather than only focusing on their rational criteria of choice.

The proposed expression could work as a basis for characterizing different types of active sport tourists: to every sport or family of sports corresponds a specific play, with specific pleasures, feelings, rules, references and so on. Thus, formalizing those different play styles could provide tailored frameworks for creating offers and experiences fitting each category of tourists. It is a way of enriching the 'consumer profiles' analyses, by once again replacing the economic behaviours among other dimensions, as only one of the aspects of practices.

'Playing with space' pinpoints some of the essential elements of both sport and tourism: their leisurely nature, their essential link with mobility or movement, the aesthetics and pleasure they involve. By highlighting their similarities, the boundaries between these social phenomena seem to blur. And indeed, the playing with space approach acknowledges that, to a certain extent, the field of leisure practices is evolving, as other demarcations are fading as well: between the daily and the exceptional, or between home and away, for instance. Hence, if 'playing with space' is an effective way of thinking about active sport tourism practices, it may also directly address some of the major evolutions of leisure cultures in contemporary societies. And as active sport tourism has become, for many people, no less than a lifestyle, playing with space might be an increasingly important way of life in leisure societies.

\section{Acknowledgements}

I would like to thank the two anonymous reviewers, the editor-in-chief of the special issue Dr Sean Gammon and Prof. Mathis Stock for their valuable comments and suggestions on this text, as well as Matt Dougherty for his language expertise. This research is supported by a position of $\mathrm{PhD}$ candidate and teaching assistant at the University of Lausanne. 
The Version of Record of this manuscript has been published and is available in Journal of Sport \& Tourism, 29 Dec 2016 , https://www.tandfonline.com/doi/full/10.1080/14775085.2016.1271349

\section{References}

Ardèvol, E., Roig, A., San Cornelio, G., Pagès, R., \& Alsina, P. (2010). Playful Practices: Theorising 'New Media' Cultural Production. In B. Brauchler \& J. Postill, Theorising Media and Practice (pp. 259-280). Oxford: Berghahn Books.

Baerenholdt, J. O., Haldrup, M., Larsen, J., \& Urry, J. (2004). Performing Tourist Places (New edition). Aldershot: Ashgate.

Barbieri, C., Henderson, K. A., \& Santos, C. A. (2014). Exploring memorable surfing trips. Annals of Tourism Research, 48, 277-280. http://doi.org/10.1016/j.annals.2014.06.008

Bessas, Y. (1982). La Glisse. Paris: Fayard.

Bouchet, P., \& Bouhaouala, M. (2009). Tourisme sportif. Un essai de définition socio-économique. Téoros. Revue de recherche en tourisme, 28(2), 3-8.

Bourdeau, P., Corneloup, J., Mao, P., \& Boutroy, É. (2004). Les interactions entre cultures sportives de montagne et territoires : un état des lieux de la recherche française depuis 1990. Cahiers de Géographie Du Québec, 48(133), 33-46. http://doi.org/10.7202/009761ar Bourdieu, P. (1972). Esquisse d'une théorie de la pratique. Paris: Droz.

Brymer, E., \& Gray, T. (2009). Dancing with nature: rhythm and harmony in extreme sport participation. Journal of Adventure Education \& Outdoor Learning, 9(2), 135-149. http://doi.org/10.1080/14729670903116912

Caillois, R. (1958). Les jeux et les hommes: le masque et le vertige. Paris: Gallimard.

Couldry, N. (2010). Theorising Media as Practice. In B. Brauchler \& J. Postill, Theorising Media and Practice (pp. 35-54). Oxford: Berghahn Books.

Crang, M. (2004). Cultural Geographies of Tourism. In A. A. Lew, C. M. Hall, \& A. M. Williams (Eds.), A companion to tourism. Malden, MA: Wiley-Blackwell.

Crouch, D. (2000). Places around us: embodied lay geographies in leisure and tourism. Leisure Studies, 19(2), 63-76. http://doi.org/10.1080/026143600374752

Csikszentmihalyi, M. (1975). Beyond Boredom and Anxiety. San Francisco, CA: Jossey-Bass Publishers.

Csikszentmihalyi, M. (1991). Flow: The psychology of optimal experience. New York: Harper Perennial.

Debarbieux, B. (2003). Imaginaire géographique. In J. Lévy \& M. Lussault (Eds.), Dictionnaire de la géographie et de l'espace des sociétés (pp. 489-491). Paris: Belin.

Dechamboux, L. (2015, March). Les Calanques, le Cap Canaille et le Trou du Diable. Grimper, (162), 108-112.

Dumazedier, J. (1962). Vers une civilisation du loisir? Paris: Seuil. 
Edensor, T. (2000). Staging tourism: tourists as performers. Annals of Tourism Research, 27(2), 322-344. http://doi.org/10.1016/S0160-7383(99)00082-1

Elias, N., \& Dunning, E. (1986). Quest for excitement: Sport and leisure in the civilizing process. Oxford: Blackwell.

Équipe MIT. (2002). Tourismes. 1. Lieux communs. Paris: Belin.

Gammon, S. (2015). Sport Tourism Finding Its Place? In S. Gammon \& S. Elkington (Eds.), Landscapes of Leisure - Space, Place and Identities (pp. 110-122). New York, NY: Palgrave Macmillan.

Gammon, S., \& Robinson, T. (1997). Sport and tourism: a conceptual framework. Journal of Sport \& Tourism, 4(3), 11-18. http://doi.org/10.1080/10295399708718632

Gibson, H. J. (2006). Towards an Understanding of 'Why Sport Tourists Do What They Do'. In H. J. Gibson (Ed.), Sport Tourism : Concepts and Theories (pp. 68-85). New York, NY: Routledge.

Gibson, H. J. (1998a). Active sport tourism: who participates? Leisure Studies, 17(2), 155-170. https://doi.org/10.1080/026143698375213

Gibson, H. J. (1998b). Sport Tourism: A Critical Analysis of Research. Sport Management Review, 1(1), 45-76. http://doi.org/10.1016/S1441-3523(98)70099-3

Glyptis, S., \& Jackson, G. (1993). Sport and tourism: mutual benefits and future prospects.

Presented at Leisure in Different Worlds, Third International Leisure Studies Association conference, Loughborough University, UK.

Goffman, E. (1973). La mise en scène de la vie quotidienne 1 : La présentation de soi. Paris: Les Editions de Minuit.

Green, B. C., \& Chalip, L. (1998). Sport tourism as the celebration of subculture. Annals of Tourism Research, (2), 275-291. https://doi.org/10.1016/S0160-7383(97)00073-X

Gregory, D. (1994). Geographical imaginations. Cambridge, MA: Blackwell.

Gregory, D. (2009). Spatiality. In D. Gregory, R. Johnston, G. Pratt, M. Watts, \& S. Whatmore, The Dictionary of Human Geography (pp. 715-717). Malden, MA: Blackwell.

Hall, C. M. (2005). Reconsidering the Geography of Tourism and Contemporary Mobility. Geographical Research, 43(2), 125-139. http://doi.org/10.1111/j.1745-5871.2005.00308.x

Higham, J., \& Hinch, T. (2006). Sport and Tourism Research: A Geographic Approach. Journal of Sport \& Tourism, 11(1), 31-49. http://doi.org/10.1080/14775080600985267

Huizinga, J. (1938). Homo ludens: proeve fleener bepaling van het spel-element der cultuur. Haarlem: Tjeenk Willink. 
Humberstone, B. (2011). Embodiment and social and environmental action in nature-based sport: spiritual spaces. Leisure Studies, 30(4), 495-512. https://doi.org/10.1080/02614367.2011.602421

Jones, I., \& Green, B. C. (2006). Serious Leisure, Social Identity and Sport Tourism. In H. J. Gibson (Ed.), Sport Tourism: Concepts and Theories (pp. 32-49). New York: Routledge.

Kane, M. J., \& Zink, R. (2004). Package adventure tours: markers in serious leisure careers. Leisure Studies, 23(4), 329-345. http://doi.org/10.1080/0261436042000231655

Kulczycki, C. (2014). Place meanings and rock climbing in outdoor settings. Journal of Outdoor Recreation and Tourism, 7-8, 8-15. http://doi.org/10.1016/j.jort.2014.09.005

Kurtzman, J., \& Zauhar, J. (2003). A Wave in Time - The Sports Tourism Phenomena. Journal of Sport \& Tourism, 8(1), 35-47. https://doi.org/10.1080/14775080306239

Lamont, M. (2014). Authentication in sports tourism. Annals of Tourism Research, 45, 1-17. http://doi.org/10.1016/j.annals.2013.11.003

Lévy, J., \& Lussault, M. (2013). Espace. In J. Lévy \& M. Lussault (Eds.), Dictionnaire de la géographie et de l'espace des sociétés (pp. 353-360). Paris: Belin.

Lewis, N. (2000). The Climbing Body, Nature and the Experience of Modernity. Body \& Society, 6(3-4), 58-80. http://doi.org/10.1177/1357034X00006003004

Loret, A. (1995). Génération glisse: dans l'eau, l'air, la neige... Paris: Éd. Autrement.

Lussault, M. (2007). L'homme spatial: la construction sociale de l'espace humain. Paris: Éd. du Seuil.

Lussault, M., \& Stock, M. (2010). 'Doing with space': towards a pragmatics of space. Social Geography, 5(1), 11-19. http://doi.org/10.5194/sg-5-11-2010

Massey, D. B. (2005). For space. London; Thousand Oaks, CA: Sage.

Ness, S. A. (2011). Bouldering in Yosemite: Emergent Signs of Place and Landscape. American Anthropologist, 113(1), 71-87. http://doi.org/10.1111/j.1548-1433.2010.01307.x

Pearce, P. L., \& Caltabiano, M. L. (1983). Inferring travel motivation from travelers' experiences. Journal of Travel Research, 22(2), 16-20.

Pearce, P. L., \& Moscardo, G. M. (1985). The relationship between travellers' career levels and the concept of authenticity. Australian Journal of Psychology, 37(2), 157-174.

Pigeassou, C. (2004). Le tourisme sportif : une réalité sociale aux contours incertains. In C. Sobry, Le tourisme sportif (pp. 33-71). Villeneuve d'Ascq: Presses Universitaires du Septentrion. Pigeassou, C., Bui-Xuan, G., \& Gleyse, J. (2003). Epistemological Issues on Sport Tourism: Challenge for a New Scientific Field. Journal of Sport \& Tourism, 8(1), 27-34. http://doi.org/10.1080/14775080306241 
Pociello, C. (1999). Les Cultures sportives : pratiques, représentations et mythes sportifs, $3 e$ édition. Paris: Presses universitaires de France.

Ponting, J. (2008). Consuming Nirvana: An exploration of surfing tourist space. University of Technology, Sydney. Retrieved from https://opus.lib.uts.edu.au/research/handle/10453/19997

Ponting, J., \& McDonald, M. G. (2013). Performance, agency and change in surfing tourist space. Annals of Tourism Research, 43, 415-434.

Rickly-Boyd, J. M. (2012). Lifestyle climbing: Toward existential authenticity. Journal of Sport \& Tourism, 17(2), 85-104. http://doi.org/10.1080/14775085.2012.729898

Rossiter, P. (2007). Rock Climbing: On Humans, Nature, and Other Nonhumans. Space and Culture, 10(2), 292-305. http://doi.org/10.1177/1206331206298546

Schatzki, T. R. (1991). Spatial ontology and explanation. Annals of the Association of American Geographers, 81(4), 650-670.

Schatzki, T. R. (2001). Introduction: practice theory. In T. R. Schatzki, K. Knorr-Cetina, \& E. Von Savigny, The practice turn in contemporary theory (pp. 10-23). London; New York: Routledge.

Schatzki, T. R. (2015). Spaces of Practices and of Large Social Phenomena. EspacesTemps.net, Traverses. Retrieved from http://www.espacestemps.net/articles/spaces-of-practices-and-oflarge-social-phenomena/

Schatzki, T. R., Knorr-Cetina, K., \& Von Savigny, E. (2001). The practice turn in contemporary theory. London; New York: Routledge.

Sheller, M., \& Urry, J. (Eds.). (2004). Tourism mobilities: places to play, places in play. London; New York: Routledge.

Shipway, R., King, K., Lee, I. S., \& Brown, G. (2016). Understanding cycle tourism experiences at the Tour Down Under. Journal of Sport \& Tourism, 20(1), 21-39. https://doi.org/10.1080/14775085.2016.1155473

Shipway, R., \& Stevenson, N. (2012). Experiencing sport tourism. Journal of Sport \& Tourism, 17(2), 81-84. https://doi.org/10.1080/14775085.2012.729897

Slanger, E., \& Rudestam, K. E. (1997). Motivation and disinhibition in high risk sports: Sensation seeking and self-efficacy. Journal of Research in Personality, 31(3), 355-374.

Spinney, J. (2006). A place of sense: a kinaesthetic ethnography of cyclists on Mont Ventoux. Environment and Planning D: Society and Space, 24(5), 709-732. https://doi.org/10.1068/d66j

Standeven, J., \& De Knop, P. (1998). Sport Tourism (1 ${ }^{\text {st }}$ edition). Champaign, IL: Human Kinetics. 
Stebbins, R. A. (1992). Amateurs, professionals, and serious leisure. Montréal: McGill-Queen's University Press.

Stock, M. (2006). L'hypothèse de l'habiter poly-topique : pratiquer les lieux géographiques dans les sociétés à individus mobiles. Electronic Journal of Humanities and Social Sciences.

Retrieved from http://www.espacestemps.net/en/articles/lrsquohypothese-de-lrsquohabiterpoly-topique-pratiquer-les-lieux-geographiques-dans-les-societes-a-individus-mobiles-en/

Thorpe, H. (2014). Transnational mobilities in action sport cultures. New York: Palgrave Macmillan.

Thorpe, H., \& Rinehart, R. (2010). Alternative sport and affect: non-representational theory examined. Sport in Society, 13(7-8), 1268-1291. http://doi.org/10.1080/17430431003780278

Tuan, I.-F. (1977). Space and place: the perspective of experience. Minneapolis, MN: University of Minnesota Press.

Uriely, N. (2005). The tourist experience: Conceptual Developments. Annals of Tourism Research, 32(1), 199-216. http://doi.org/10.1016/j.annals.2004.07.008

Urry, J., \& Larsen, J. (2011). The tourist gaze 3.0. Los Angeles, CA: Sage.

Varley, D. P. (2006). Confecting Adventure and Playing with Meaning: The Adventure

Commodification Continuum. Journal of Sport \& Tourism, 11(2), 173-194. http://doi.org/10.1080/14775080601155217

Victor, E. (1981, August 20th). Yves Bessas présente les sports de glisse. Génération 1 (TV show). Retrieved from http://www.ina.fr/video/CAA8101234601

Weed, M. (2006). Sports Tourism Research 2000-2004: A Systematic Review of Knowledge and a Meta-Evaluation of Methods. Journal of Sport \& Tourism, 11(1), 5-30. http://doi.org/10.1080/14775080600985150

Weed, M., \& Bull, C. J. (2009). Sports Tourism: Participants, Policy and Providers. Oxford: Elsevier.

Wheaton, B. (2004). Understanding lifestyle sports: consumption, identity, and difference. London; New York: Routledge.

Woermann, N. (2012). On the Slope Is on the Screen: Prosumption, Social Media Practices, and Scopic Systems in the Freeskiing Subculture. American Behavioral Scientist, 56(4), 618640. http://doi.org/10.1177/0002764211429363

\section{Notes}


1 'un déplacement (organisateur d'un espace-temps touristique) initié par un environnement (spécifié par la destination) et par la participation à des phénomènes caractéristiques de la culture sportive ludique comprise comme expression d'une activité motrice et/ou de manifestations culturelles', personal translation.

2 'Habiter'; the French term might stress a little less the 'anchoring' dimension, but has still been traditionally viewed as antagonistic with mobility.

${ }^{3}$ This exact expression is suggested, but not developed, in Lussault \& Stock's article (p.15).

${ }^{4}$ For example: 'The top seven summer surf trips in the United States', by Josh T. Saunders, posted on June 24, 2015, Surfer: http://www.surfermag.com/features/top-seven-summer-surf-trips-inusa/\#tW5jKUrHdYSO17FA.97.

${ }^{5}$ For example: 'Vacation climbing in Kalymnos, Greece', by Julie Ellison, Climbing, May 2016 issue.

${ }^{6}$ See for the magazines: Canoe\&Kayak Summer 2016 'Travel Issue'; Grimper Spécial Tour du Monde ('World Tour Special Issue'), 2007, issue 100. See for the websites: http://www.surfline.com/travel/; http://www.canoekayak.com/travel/; http://climbingaway.fr/en/; https://www.trailrunproject.com/.

${ }^{7}$ Although Google Earth was not the first virtual globe to be released, its unprecedented rapidity and precision made it the most popular of these tools.

${ }^{8} \mathrm{http} / / /$ www.chillaz.com/product/men/men-longsleeve/id-203117.html\#/0

9 'tu dois apprendre non pas à te battre avec la nature, mais plutôt à faire l'amour avec, c'est-à-dire à la découvrir, à l'aimer, et finalement à jouer avec.' Personal translation.

10 'un lieu [...] où l'on grimpe pour soi, pour profiter de l'essence du lieu, du cadre sublime, de l'ambiance et de l'air salé.' Personal translation

${ }^{11}$ Online collaborative guides such as http://www.camptocamp.org/ for mountain sports, collaborative forecasts such as http://magicseaweed.com/ for surfing, these websites also contain discussion forums.

${ }^{12}$ See for example GoPro's website channel page (https://gopro.com/channel/), with categories such as 'Life's Moments' or 'Furry Friends'; and among the 'Videos of the day', see for instance the following user-uploaded ones: 'Monkey Temple' (https://gopro.com/channel/video-of-the-day/monkey-temple); 'Sun Island Maldives 2015' (https://gopro.com/channel/video-of-the-day/sun-island-maldives-2015). 